\author{
Urszula ZAGÓRA-JONSZTA, Professor \\ University of Economics in Katowice \\ e-mail: urszula.zagora-jonszta@ue.katowice.pl \\ ORCID: 0000-0003-4904-1025
}

DOI: $10.15290 /$ oes.2018.04.94.11

\title{
POLAND'S GREATEST INFLATIONS OF PAST CENTURY
}

\begin{abstract}
Summary
The paper discusses the reasons for the deepest inflations of the past century in Poland, their course, and ways to overcome them. The analysis concerns the inflation of the Polish mark, the subsequent coin inflation, and the inflation of the turn of the 1980s and 1990s.

The author's aim is investigate the characteristics of those inflations and the factors which caused them. The methods used include source analysis, comparative analysis, and the descriptive method. The study is based on the work of pre-war and contemporary authors, using statistical data from the Central Statistical Office.
\end{abstract}

Key words: socio-economic system, inflation, anti-inflation policy

JEL classification: N1, B1, B2

\section{Introduction}

It is 100 years since Poland regained its independence. After 123 years of the country's absence from the political map of Europe, the Polish state was re-established, although its borders were still far from being clearly defined. The shape of the Second Polish Republic had to be contended for through both diplomatic and military means. Over the past century, the Polish economy has struggled with a variety of problems, including inflation. The purpose of the paper is to overview the most serious inflations in Poland, their causes, course, intensity, and attempts to overcome them. The conducted analysis reveals that each of the inflations had different origins and characteristics. Regardless of the political system in place, inflation has affected Poland's economy many a time, causing not only economic repercussions, but also social ones. 


\section{Inflation of the mark}

Having regained independence in November, 1918, the young Polish state faced a number of tasks to be accomplished as rapidly as possible. The numerous problems included:

- the necessity to unite three separate sections of the country into a single state organism,

- the need to rebuild the economy (wartime damage and deliberate destruction by the former invaders),

- continued wartime economy resulting from the war with Russia,

- withdrawal of foreign (and often Polish) capital from the territory of the new state,

- the necessity to stimulate the industrial sector by means of state subsidies and loans,

- multicurrency and the necessity to unify currency,

- diplomatic and military strife for borders,

- domestic political skirmishes.

All that required enormous amounts of money, and since no private capital was available, the brunt of the burden had to be borne by the state.

As J. Zdziechowski [1925, p. 12; 1937, p. 292; 2005]. calculated, within the first five years of independence, state subsidies to the industrial sector amounted to as much as $675 \mathrm{~m}$ złotys. The Polish-Russian war of the 1920s was also extremely costly. As a result, by 1926, a state deficit had become part and parcel of the country's finances. Domestic and foreign loans, willingly offered by Western governments, mindful of the Bolshevik threat, were a considerable, though insufficient, boost for the Polish economy. After the war with Russia had ended, however, that form of aid dried up. The volume of domestic loans also shrank every year, which indicated a depletion of national capital.

The fact that the former partitions used different currencies, and the varying exchange rates between them made trade more difficult. ${ }^{1}$ Therefore, in November 1919, the government decreed that the Polish mark would become the sole legal tender in the entire country, which took effect in mid-1920 [Karpiński, 1968, p. 39] (in Upper Silesia, formally, on the 1st of November, 1923). Because of the growing need to finance the economy, the government was compelled to print more and more notes of ever higher denominations, which led to the gradual devaluation of the Polish mark. Inflation swelled and became rampant. All the attempts to counteract it ended in failure. The frequently changing ministers of finance introduced new taxes, tributes, and compulsory loans, but they did so cautiously, not wishing to

1 The other currencies which were then in circulation on the territory of Poland included: German marks, Austrian kronen, roubles, hryvnias, etc. Polish marks were issued by Polska Krajowa Kasa Poizycrkowa (The Polish National Loan Association) established in December 1916 by the German authorities of the General Government of Warsaw. 
discourage industrialists, landowners and other citizens, and were thus unable to stop the inflation. The rate of its growth is illustrated by table 1 .

TABLE 1

Exchange rate of US dollar to Polish mark (Polish mark inflation rate)

\begin{tabular}{|c|c|c|}
\hline Date & Dollars & Polish marks \\
\hline 12.11 .1918 & 1 & 8.00 \\
\hline 31.01 .1919 & 1 & 110.12 \\
\hline 31.12 .1920 & 1 & 590.00 \\
\hline 31.12 .1921 & 1 & $2,922.50$ \\
\hline 31.12 .1922 & 1 & $17,800.00$ \\
\hline 31.12 .1923 & 1 & $6,375000.00$ \\
\hline 27.04 .1924 & 1 & $9,250.00 .00$ \\
\hline
\end{tabular}

Source: [Zientara et al., 1973, p. 568].

In autumn 1919, the Polish mark had lost so much value that people began to invest their savings in foreign hard currency. Economists warned against the negative consequences of such policies, calling for immediate cessation of money issuance and restriction of expenditures. According to the precepts of the then prevalent liberal economics, a strong, stable currency and budget balance guaranteed a robust economy [Krzyżanowski, 1932; Taylor, 1929]. That approach was unpopular with large capital owners and landed gentry as, at least initially, they benefited from inflation. Whenever they delayed paying taxes, which the government failed to revalue or did so too late, they effectively paid much less than was due. The effects of inflation were most keenly felt by those on fixed incomes, i.e. the working masses. The value of the so-called inflationary tax, i.e. the loss sustained by the owner of the marks as a result of the decline in their purchasing power, has been differently estimated, but all the estimations are staggering. T. Szturm de Sztrem [1923, p. 49] claimed it amounted to $\$ 809 \mathrm{~m}$ in the years 1918-1924, J. Zdziechowski estimated it at $\$ 533$ m [Landau, Tomaszewski, 1967, p. 288], while S. Starzyński [1928, p. 9] at $\$ 736 \mathrm{~m}$. The highest estimate of the cost of inflation - $\$ 2$ billion - was given by E. Taylor [1926a, p. 280]. Even though numerous strategies for restoring the health of Poland's public finances were proposed, the situation was increasingly difficult. Many economists suggested that a unit of account be established, whose value in Polish marks would be periodically adjusted based on the exchange rates of the dollar of franc [Młynarski, 1921, 1922, 1924; Rybarski, 1922, p. 216; Zweig, 1923, p. 40]. The extent of the depreciation of the Polish mark against the dollar increased as follows: $1919-321 \%, 1920-253 \%, 1921-509 \%, 1922-602 \%, 1923-35,430 \%$ [Taylor, 1926a, p. 68]. In early autumn 1923, Poland entered the stage of hyperinflation (inflationary catastrophe) [Nowak, 1932, p. 240], which in November prompted groups of workers in Cracow to resort to street riots, bloodily suppressed by government armed forces. 
Economists suggested two different methods to boost the currency. The conservative Cracow school recommended that the state budget first be balanced through converting the mark into a new currency, as well as incurring a foreign loan. The innovative Warsaw school advocated adjusting the value of taxes and domestic loans, arguing that a budgetary equilibrium was impossible to achieve. By the end of 1922, the government had favoured the solution suggested by the Cracow school. It was only in January 1923 that W. Grabski, professor at the Warsaw University of Life Sciences, for the second time took the office of the Minister of Treasury, and in March presented to the Sejm (lower chamber of the Polish parliament) a draft Act on the Improvement of the Treasury. As the project met with disapproval (it involved, e.g. covering the deficit with revenue obtained from a contingency tax on property and strict austerity measures), Grabski stepped down from his post on 1st July. In December, he became Minister of Treasury for the third time, holding at the same time the position of Prime Minister. The situation was already very tense and required immediate action. In October 1923, prices were by $360 \%$ higher than in the previous month. At the beginning of June, one U.S. dollar cost 71,000 Polish marks, two months later, its price soared to 230,000 marks, and in October it reached one million marks [Jędruszczak, 1978, pp. 204-205]. Fearing social unrest, the Sejm passed the Act on State Treasury and Currency Reform [1924]. It was agreed that several taxes (industrial, land, property, salary, pension, and indirect ones) would be raised and that a contingency tax would be levied on private property, which proved to play a significant role in the reform. State expenditures were reduced. The project assumed that the reform should be financed from domestic resources, without any recourse to foreign aid. This was met with the objection of the representatives of the Cracow school, who demanded, in the Sejm and in the press, that the government made an agreement with the League of Nations in order to take out a foreign loan. The most important task was to achieve a budget equilibrium and to replace the devalued Polish mark with a new currency: the złoty. In February 1924, bank notes for treasury purposes ceased to be printed. On the 28th April, 1924, a new central bank - Bank Polski SA - was established, replacing Polska Krajowa Kasa Posyczkowa (Polish National Loan Association), and commenced issuance of the new legal tender. The złoty was based on a $1 / 31 \mathrm{~g}$ gold parity (the equivalent of the Swiss franc). The Polish marks were exchanged for złotys at the rate of 1 złoty $=1.8 \mathrm{~m}$ Polish marks. One U.S. dollar cost 5.18 zł. Grabski's reform was accomplished "on our own", solely thanks to internal financing resources, without any foreign aid. ${ }^{2}$

\section{Coin inflation}

In the middle of 1924, customs tariffs were reduced, which many saw as the reason for another currency crisis. After a short period of relative stability in 1924

2 This is the title of one of his publications, written as a response to criticism by A Krzyżanowski [see: Grabski, 1926]. 
(the state budget was largely balanced) [Kaliński, Landau, 2003, p. 75], ${ }^{3}$ the beginning of the following year brought a deterioration of the economic outlook. The government attempted to counterbalance the rising deficit by issuing coins and treasury notes. At least $30 \%$ of the value of the bank notes in currency was to be based on the stocks of gold bullion and hard currency stored by the Bank Polski SA. The bank notes could be exchanged for gold or foreign currency at the BP SA. The government had the right to mint coins and issue the so-called treasury notes, i.e. halved Polish mark notes stamped to indicate their new value: from 1 to 50 groszy (in May 1925, 2-złoty and 5-złoty notes were also introduced). The amount of fiat money in circulation kept growing. The treasury notes were to be valid until an appropriate number of the new coins was minted [ędruszczak, 1978, p. 284].

At the beginning of 1925, foreign exchange revenues of the BP SA began to dwindle, while demand for foreign currency among importers kept growing. There were several reasons for this state of affairs. Because of the bad harvest of 1924, about $200 \mathrm{~m}$ złotys had to be spent on increasingly expensive food imports. To make matters worse, the prices of Poland's basic exports (sugar, timber, and coal) had fallen, which affected our terms of trade. F. Młynarski [1971, pp. 231-232] estimated the resultant losses in export earnings at approx. $400 \mathrm{~m}$ złotys. In June 1925, after the Upper Silesia Agreement ${ }^{4}$ had expired, Germany refused to continue buying coal from Silesian mines, and a customs war - very inconvenient for Poland - started. In August, free trade in foreign currency and gold bullion was reinstated. Another reason behind the shrinking currency reserves of the BP SA was the increasing reluctance of foreign partners to grant credits to Polish entrepreneurs, or even withdrawal of previously granted ones [Pszczółkowski, 1927, p. 92; Morawski, 2008, p. 113].

In October 1924, Poland once again fell into the spiral of inflation. In the first quarter of 1925, the total value of the coinage in circulation grew by $66 \mathrm{~m} \mathrm{zl}$, in the second quarter - by $54 \mathrm{~m} \mathrm{zl}$, and in the third - by another $99 \mathrm{~m}$ zl. The amount of newly-minted coins exceeded the statutory limit of $12 \mathrm{zł}$ (raised from $9.5 \mathrm{z}$ ).Poland effectively had two currencies: the złoty notes had gold backing, while the coins did not. The salaries of civil servants were paid half in bank notes and half in coins. The latter could not be used to purchase foreign currency and were often not accepted by banks. It sometimes happened that bank notes were exchanged for coins or treasury notes at a rate higher than their nominal value [Morawski, 2008, p. 114]. The BP SA officially introduced two types of accounts: for złoty bank notes and for coins or treasury notes. A large amount of the Polish złotys had been invested in foreign stock exchanges, but they could not be exchanged into other currencies. One dollar cost there 5.8-6.0 zl [Karpiński, 1958, p. 36], compared with the official exchange rate of $5.18 \mathrm{z}$. As the production volumes were decreasing, the amount of money in circulation should have been shrinking as well, but instead it grew by $51 \%$

\footnotetext{
W. Morawski [2008, p. 111] writes that the budget deficit amounted to $173 \mathrm{~m} \mathrm{zl}$.

4 The agreement obliged Germany to purchase 6 million tons of coal from Upper-Silesian mines every year.
} 
between June 1924 and September 1925, which, of course, caused prices to rise [Barański, 1926, p. 47]. In order to put a stop to the falling exchange rates of the złoty, the BP began to interfere in the stock exchange processes. It sold foreign currency at parity prices and bought it at higher, current ones. The costs of that interference were high, the supply of foreign currency waned rapidly, and the foreign intervention credits which the government incurred proved insufficient. In spite of a temporary improvement in August and September, the spectre of the inflationary spiral still loomed large over the Polish economy. E. Taylor [1926, p. 65] claimed that the only way out was to withdraw $200 \mathrm{~m}$ złotys worth of treasury notes. Others suggested, e.g. issuing a new internal currency, the so-called 'złoty rentowy' (W. Diamand, R. Battaglia, S. Jabłoński). Most experts were convinced that it was of overriding importance that a foreign loan be taken out to stabilise the złoty and to seek the protection of the League of Nations. Grabski rejected that concept, wary of foreign intrusion into Poland's finances. In autumn, the process of abandoning the złoty became even more evident. With the memory of the recent inflation of the mark still fresh in their minds, people reacted nervously, withdrawing savings, selling złotys, and buying stronger, foreign currencies and gold. Despite much effort, it proved impossible to maintain a stable rate of exchange. On 12th November, 1925, the president of the Bank of Poland, S. Karpiński, refused to continue the interventionist policies aimed at sustaining the value of the złoty. In consequence, the rate of exchange between the Polish currency and the dollar plummeted overnight from 6.2 to 6.9 zł. Following that conflict, Grabski's government tendered its resignation the very next day [Morawski, 2008, p. 120].

J. Zdziechowiecki, the next minister of the treasury, attempted to balance the budget by raising taxes and levies, reducing expenditure (salaries and pensions), and stopping the production of coins. In July 1926, the value of treasury notes and coins in the market reached $469 \mathrm{~m}$ złotys, after which their number began to dwindle. In the summer of that year, a budget equilibrium was at last secured [Morawski, 2008, p. 129].

Many economists (J. Zdziechowski, A. Krzyżanowski, E. Taylor) believed that the złoty was too strong, claiming that its value should equal a fraction of the Swiss franc. According to Taylor, however, the problems had primarily been caused by too abrupt a transition from a small currency unit (the Polish mark) to a large one. Because of that, the złoty was underappreciated, people spent money too quickly and failed to make savings [Taylor, 1926, p. 9]. Taylor criticised the credit policies of the BP SA as superficial and passive, adding that the incompetence of Polish banks had contributed to the complete chaos at the capital market. This caused the rise in prices which destabilised the zloty [Taylor, 1926, p. 33]. The authorities tried to maintain the exchange rate at all costs, which resulted in an outflow of gold and foreign currency reserves from the BP SA, depriving the złoty of its backbone of stability [Taylor, 1926, p. 61]. Poland's trustworthiness was rapidly declining. 
A. Krzyżanowski [1926, pp. 102-103] believed that this had been caused by excessively high taxes and the inability of foreigners to purchase real estate in Poland. ${ }^{5}$

Grabski himself wrote that he had been unable to foresee the crop failure of 1924, that our terms of trade would worsen, that the Sejm would raise budget expenditure, causing a growth of budget deficit, that a customs war with Germany would break out, and that the second issue of the Dillon loan would fail to reach Poland in time. He also criticised the policy of the BP SA as misguided [Grabski, 1927, p. 117].

Pre-war economists identified a number of reasons for the coin inflation. Among the most important ones were:

- Lack of a transition period when Polish marks would be gradually withdrawn from circulation (E. Taylor, F. Zweig);

- The overly high exchange rate of the złoty, especially given the state of the Polish economy, as a result of which most small transactions were made by means of small change (A. Krzyżanowski, E. Taylor);

- Passive balance of trade, budget deficit, combined with the fact that it was needlessly covered with coins, free trade in foreign currency (A. Krzyżanowski, S. Karpiński);

- Excessive state expenditure covered with issuance of coins (E. Taylor, A. Krzyżanowski);

- Too high long-term credits and excessive tax burdens (A. Krzyżanowski);

- Negative balance of trade because of too low rates of duty (F. Młynarski);

- $\quad$ Lack of a stability loan (F. Młynarski, F. Zweig, S. Głąbiński, H. Tennenbaum);

- Crop failure, worsening of exchange terms (F. Młynarski).

The authors of post-war and modern publications pay particular attention to:

- Excessively high rate of exchange of the złoty [Karpiński, 1968, p. 85; Szymczak, 1959, p. 21];

- The consequences of the customs war and a decline in the inflow of foreign currency [Kaliński, Landau, 2003, p. 78; Morawski, 2008, p. 113];

- Bad harvest and flood, deterioration of the terms of exchange, introduction of free trade in foreign currency and precious metals [Jędruszczak, 1978, pp. 281-286; Morawski, 2008, p. 107];

- low property tax collectability and failure to receive the second instalment of the Dillon loan [Morawski, 2008, pp. 111-113].

Apart from the above reasons, the coin inflation seems to have been triggered by the 'inflationary psychosis' which had taken a grip of many Polish citizens not very long before, when the mark's value plummeted, making them react nervously to the first symptoms of another. The same 'psychosis' brought about the deflationary policies of the Great Depression, which were extremely harmful to our economy.

5 Those were by no means the only reasons. J. Tomaszewski [1961, p. 195] also writes about the anti-Polish activity of some global financial centres. 
If Poles had behaved in a more restrained manner and if they had had more trust in the złoty, the effects of the coin inflation could even have been barely perceptible.

After Grabski had stepped down, Poland began to endeavour to obtain a stability loan, as the most distinguished economic experts insisted. In October, 1927 , the government issued an ordinance on a stability plan and incurring a loan of $\$ 62 \mathrm{~m}$ and $f 2 \mathrm{~m}$ for its implementation. The złoty was devalued by $42 \%$ against the 1924 parity. The exchange rate of the złoty to the U.S. dollar stabilised at 8.91, the coverage of the zloty was raised to $40 \%$, and the amount of coinage in circulation was reduced to $320 \mathrm{~m}$ zł [Karpiński, 1968, p. 104].

\section{Inflation of the 1980s and 1990s}

Our economy suffered another inflation in the so-called Gierek decade. The increased standard of living achieved in the 1970s and the strategy of dynamic socioeconomic development gave rise to snowballing inflation processes [Kołodko, 1987, p. 174]. In 1974, prices rose considerably. Between 1973 and 1977, they grew on avarege by $3.5 \%$ to $5 \%$ a year (creeping inflation), while incomes, and particularly salaries, increased on average by $13.3 \%$ [Tymowski, 1980, p. 77]. This was neither justified by labour efficiency, which had begun to decline, nor by the dynamics of production. In order to dampen consumer demand, the government increased the prices of some randomly selected industrial products, which became one of the main factors contributing to inflation. Admittedly, the price rises helped decrease the demand inflation, but they exacerbated the cost inflation. Approximately a quarter of the capital expenditures was made up by employee incomes, which exerted pressure on the market, but because of the prevalent long-term investments, the demand could not be met. The costly imports from Western countries were insufficient. This entailed a continuous growth of prices of consumer goods: in 1973-1979, they rose by over 39\%. An attempt to balance the market by raising the prices of food ended in a wave of strikes and street riots [Górski, 1983, p. 12].

Since the beginning of the 1970s, the government had been taking out foreign credits, which initially mitigated the supply and investment problems. At the end of 1980, Poland's debt to the West amounted to $\$ 24.1$ b [Maty rocznik statystyczny, 1990, p. 232; Kołodko, 1990, pp. 58-59]. In the second half of the 1970s, economic growth began to slow down. In 1979, national income fell by $4 \%$ in relation to the previous year, while in 1980 - by 6\%. The government was losing control of the investment and production processes.

The situation deteriorated even further in the 1980s. At the beginning of the ninth decade of the twentieth century, the imbalance affected $80 \%$ of the consumer goods industry. Rationing, queues, and under-the-counter buying fuelled discontent among the population. The rise in the prices of some of the products, announced on July 1st, 1980, provoked another wave of strikes. People demanded higher wages, salaries, and other employee benefits. The government gave in, as a result of which inflation climbed to ca. 10\% [Jezierski, Leszczyńska, 1997, pp. 468-470]. Measures 
taken to reform the socialist economy, developed by a committee led by W. Baka, failed to produce expected results. The wage demands accelerated the spiral of inflation; in the second half of the 1980s, an additional $140 \mathrm{~b}$ zk, which did not have coverage in commodities, flowed into the market; the monetary overhang grew to 300 b zł [Kołodko, 1987, p. 211; Kosecki, 1988, p. 48].

At the end of the 1980s, the pace of inflation quickened. The Polish economy entered the phase of hyperinflation. Although the subsequent five-year plan for the years 1986-1990 assumed restoring economic balance and curbing inflation, in practice, wages and other budget expenditures kept rising, and the budget deficit continued to be covered by additionally printed money, which eventually made inflation soar. August 1989 brought what might be referred to as hyperinflation, which reached its peak at the turn of 1989 and 1990. The so-called shortageflation syndrome occurred, i.e. a shortage stemming from price/supply inflation. Also price (open) inflation and suppressed inflation were escalating [Kołodko, 1999, p. 43; Ba1towski, Miszewski, 2006, pp. 151-152].

In 1988, inflation increased month after month. In an attempt to ensure an economic balance, the still-socialist government progressively raised official prices, and contract prices kept growing as well. As the situation worsened, popular discontent and uproar continued to increase: there appeared calls for changing the political system and marketisation of the economy. The Round Table Agreement and the partly free democratic election of June 1989 were an expression of political breakthrough and the first step towards a transition from a planned economy to a market economy.

Meanwhile, budget deficit associated with excessive subsidising of unprofitable state-sector production did not stop rising. Moreover, the marketisation of agriculture in August 1989 (the first step towards system transformation) caused a considerable rise in the price of food: by as much as 39.5\% in comparison with July [Kaliński, 2009, p. 51]. The situation was made even worse by the consequences of wage indexation (in August, they grew by nearly 90\%) [Balcerowicz, 1992, pp. 3637]. Additionally, Poland's debt to the West deepened massively. From $\$ 29$ b in 1985 it swelled to $\$ 40.8 \mathrm{~b}$ in 1989 , which accounted for a staggering $44 \%$ of the GDP [Kołodko, 1991, pp. 89-90] and was almost equal to six years' worth of Poland's exports revenue [Bałtowski, Miszewski, 2006, p. 154].

On January 1, 1990, the government commenced to implement the so-called Balcerowicz plan, which consisted of a stabilisation programme and a programme of systemic change. The former was to re-balance the market and quickly reduce inflation. The implementation of the programme relied on three stability anchors: immediate introduction of internal exchangeability of the złoty, its deep devaluation $(\$ 1=9,500$ złotys), and the introduction of a drastically low wage indexation rate ( 0.3 in January and 0.2 in the subsequent months). This meant that only 30 or 20 percent of real inflation was compensated for with pay rises. At the same time, the so-called 'popiwek', i.e. a super-normative wages tax, was introduced, reaching up to 500\% [Balcerowicz, 1992, pp. 42-47; Kowalik, 2000, p. 269]. In the short term, it had a clearly anti-inflationary and stabilising effect, but in the long term, it was anti- 
motivational, anti-supply side, and thus pro-inflationary. At the beginning of 1990, the real amount of money in circulation and the inflation overhang both went down. Budget expenditure was reduced and interest rates were substantially increased [Bałtowski, Miszewski, 2006, pp. 188-189]. The złoty retained its internal exchangeability, while the value of the dollar dropped 2.7-fold. In 1990-1993, the monetary resources of the population and enterprises shrank because no positive real interest rate had been introduced and bank deposits had not been (or had been only partly) re-valued. The beginning of 1990 and the following year brought, moreover, drastic rises in the prices of energy carriers, causing inflation aftershocks. Therefore, a considerable impoverishment of the population took place, accompanied by strong income disparities. The hyperinflation was successfully reined in and transformed into a gradually decreasing inflation. However, the reduction of inflation to a single figure, which Balcerowicz had promised, was only attained after 9 years. For the entire 1990, inflation amounted to nearly $600 \%$. The GDP was to decline by $3 \%$, but it fell by over $11 \%$, and by another $7 \%$ in the following year. Industrial production was to drop by $5 \%$, but it decreased by $25 \%$. The number of the unemployed was to stand at about 400,000, whereas by the end of 1990 it had reached one million, to reach 2 million in the subsequent year, and almost 3 million soon after. In 1990, wages decreased by one third and kept falling until 1994 [Kowalik, 2000, p. 270]. It turned out - not for the first time in our history - that inflation is not easy to tame. The course of the 1988-1995 inflation is illustrated by table 2 .

TABLE 2

Monthly inflation measured by consumer price index in 1988-1995 (December of the preceding year $=100)$

\begin{tabular}{|l|c|c|c|c|c|c|c|c|}
\hline Month/Year & $\mathbf{1 9 8 8}$ & $\mathbf{1 9 8 9}$ & $\mathbf{1 9 9 0}$ & $\mathbf{1 9 9 1}$ & $\mathbf{1 9 9 2}$ & $\mathbf{1 9 9 3}$ & $\mathbf{1 9 9 4}$ & $\mathbf{1 9 9 5}$ \\
\hline January & 103.7 & 111.0 & 179.6 & 112.7 & 107.5 & 104.1 & 101.8 & 104.1 \\
\hline February & 121.5 & 119.8 & 222.5 & 120.3 & 109.4 & 107.6 & 102.9 & 106.3 \\
\hline March & 128.4 & 129.4 & 232.0 & 125.7 & 111.6 & 109.9 & 105.0 & 108.0 \\
\hline April & 137.5 & 142.1 & 249.4 & 124.1 & 115.7 & 112.4 & 108.0 & 110.5 \\
\hline May & 140.9 & 152.3 & 260.9 & 130.6 & 120.4 & 114.5 & 109.9 & 112.5 \\
\hline June & 144.9 & 161.6 & 269.8 & 139.0 & 122.4 & 116.0 & 112.4 & 113.6 \\
\hline July & 149.5 & 177.1 & 279.5 & 139.1 & 124.0 & 117.3 & 114.1 & 112.5 \\
\hline August & 150.4 & 247.0 & 284.6 & 140.0 & 127.4 & 120.0 & 116.0 & 112.9 \\
\hline September & 154.6 & 331.6 & 297.7 & 146.0 & 134.1 & 123.0 & 121.3 & 116.3 \\
\hline October & 159.4 & 513.2 & 314.6 & 150.7 & 138.1 & 125.3 & 124.8 & 118.3 \\
\hline November & 165.4 & 628.2 & 330.0 & 155.5 & 141.2 & 130.4 & 127.1 & 119.8 \\
\hline December & 173.9 & 739.6 & 349.3 & 160.4 & 144.3 & 137.6 & 129.5 & 121.6 \\
\hline
\end{tabular}

Source: [www 1].

M. Dąbrowski [1995, p. 49], interpreting the above data, stated that the nearly 40-percent inflation in 1993 proved the weaknesses of the monetary policy 
implemented in Poland, as well as the persistence of factors which determined high inflationary inertia.

TABLE 3

Consumer price index in 1988-1995 (\%)

\begin{tabular}{|c|c|c|c|c|c|c|c|c|}
\hline Year & $\mathbf{1 9 8 8}$ & $\mathbf{1 9 8 9}$ & $\mathbf{1 9 9 0}$ & $\mathbf{1 9 9 1}$ & $\mathbf{1 9 9 2}$ & $\mathbf{1 9 9 3}$ & $\mathbf{1 9 9 4}$ & $\mathbf{1 9 9 5}$ \\
\hline Previous year $=100$ & 160.2 & 351.1 & 685.8 & 170.3 & 143.0 & 135.3 & 132.3 & 127.8 \\
\hline
\end{tabular}

Source: [www 1].

In the subsequent years, the rate of inflation fluctuated around a dozen percent on an annual basis, to fall to $5.5 \%$ as late as in 2001 , and to stabilise at 1 to 4 percent annually in the next few years [www 1].

\section{Conclusions}

The above brief presentation of the three most recent major inflations in Poland, their course and the methods of their control demonstrates that the causes of inflationary phenomena are manifold and that they are extremely difficult to rapidly and efficiently eliminate. Of course, low creeping inflation is not a threat. On the contrary, it can even be have a beneficial effect. It is only high inflation, capable of turning into hyperinflation, that is disquieting. The higher its rate, the more difficult it is to curb. This was acutely felt both after the First World War and at the turn of the 1980s and 1990s.

On the basis of the presented analysis of inflationary phenomena, the following conclusions can be drawn:

1. The reasons for inflation can vary, ranging from:

- economic,

- through psychological,

- to political ones.

2. It is easy to lapse into inflation, but much more difficult to overcome it.

3. Hyperinflation has a negative impact not only in economic but also in social terms.

4. Inflation can occur irrespective of socio-economic system.

5. Maintenance of financial discipline is tremendously important, but also difficult, and governments should bear this in mind.

6. Governments should learn from past mistakes and avoid repeating them.

The above analysis also indicates the fact that economics is a complex science, and that experimentation on the living organism of an economy requires making well-considered decisions and the ability to foresee all their possible consequences. Therefore, economists who are responsible for decision-making face a formidable challenge. Not only do they have to be knowledgeable about the intricacies of economic processes, but they must also remember that an economy is a system of interconnected vessels, and that even a small mistake can cause an avalanche of 
ramifications. Moreover, the future is not fully predictable, which is why even the most reasonable decisions carry the risk of negative outcomes.

\section{References}

Act on State Treasury and Currency Reform, Dz.U. RP 1924, No. 4, item 28.

Balcerowicz L., 1992, 800 dni. Szok kontrolowany, BGW, Warszawa.

Bałtowski M., Miszewski M., 2006, Transformacja gospodarcza w Polsce, Wydawnictwo Naukowe PWN, Warszawa.

Barański L., 1926, Uwagi nad obiegiem pienieżnym w Polsce, „Przemysł i Handel”, Warszawa.

Dą̧browski M., 1995, Polityka gospodarcza okresu transformacji, PWN, Warszawa.

Górski J., 1983, Ekonomia popytu a ekonomia podaży, Życie Gospodarcze, nr 12.

Grabski W., 1926, O własnych siłach, zbiór artykutów na czasie, Gebethner i Wolf, Warszawa.

Grabski W., 1927, Dwa lata pracy u podstaw państwowości naszej (1924-1925), F. Hoesick, Warszawa.

Jezierski A., Leszczyńska C., 1997, Historia gospodarcza Polski, KeyText, Warszawa.

Jędruszczak T. (ed.), 1978, Historia Polski, T. IV 1918-1939, t. 2.

Kaliński J., 2009, Transformacja gospodarki polskiej w latach 1989-2004, SGH, Warszawa.

Kaliński J., Landau Z., 2003, Gospodarka Polski w XX wieku, Polskie Wydawnictwo Ekonomiczne, Warszawa.

Karpiński Z., 1958, Bank Polski 1924-1939. Praycsynek do historii gospodarczej okeresu miedzywojennego, Polskie Wydawnictwo Gospodarcze, Warszawa.

Karpiński Z., 1968, Ustroje pienię̇ne w Polsce od 1917 roku, PWN, Warszawa.

Kołodko G.W., 1987, Polska w świecie inflacii, Książka i Wiedza, Warszawa.

Kołodko G.W., 1990, Inflacja, reforma, stabilizacja, Alma-Press, Warszawa.

Kołodko G.W., 1991, Transformacja polskiej gospodarki. Sukces cæy porażka?, BGW, Warszawa.

Kołodko G.W., 1999, Od szoku do terapii. Ekonomia i polityka transformacii, Poltext, Warszawa.

Kosecki J., 1988, Problemy równowagi rynkowej w polityce społeczno-gospodarczej, WKP/WAP, Warszawa.

Kowalik T., 2000, Systemy ekonomiczne. Powstanie, ewolucja, krysysy, Wyd. Wyższej Szkoły Przedsiębiorczości i Zarządzania im. L. Koźmińskiego, Warszawa.

Krzyżanowski A., 1926, Pauperyzacja Polski wspótczesnej, Krakowska Spółka Wydawnicza, Kraków.

Krzyżanowski A., 1932, Polityka i gospodarstwo. Pisma pomniejsze oraz.przemónienia 19201931, PAU, Kraków.

Landau Z., Tomaszewski J., 1967, Gospodarka Polski miedsynojennej, t. I - W dobie inflacji 1918-1923, Książka i Wiedza, Warszawa.

Maty rocznik statystyczny, 1990, GUS, Warszawa.

Młynarski F., 1921, Reforma ustroju pienieżnego, Wyd. M. Arcta, Warszawa. 
Młynarski F., 1922, Na przetomie kwestii walutowej, „Ignis”, Warszawa.

Młynarski F., 1924, Walka o naprawe skarbu, „Ignis”, Warszawa.

Młynarski F., 1971, W spomnienia, PWN, Warszawa.

Morawski W., 2008, Od marki do żtotego. Historia finansón Drugiej Ržecsypospolitej, Wydawnictwo Naukowe PWN, Warszawa.

Nowak H., 1932, Bankowość w Polsce, Dom Książki Polskiej, Warszawa.

Pszczółkowski S., 1927, Bilans platničyy Polski w latach 1923-1926, Gebethner i Wolff, Warszawa.

Rybarski R., 1922, Marka polska i złoty polski, Księgarnia Perzyński, Niklewicz i S-ka, Warszawa.

Starzyński S., 1928, Myśl państwowa w ṡyciu gospodarczym, [in:] Na froncie gospodarczym. $W$ driesiata rocznice odzyskeania niepodlegtości, „Droga”, Warszawa.

Szturm de Sztrem T., 1923, Żywiotowość w opodatkowaniu; podatek inflacyjny, IGS, Warszawa.

Szymczak Z., 1959, Ze studiów nad stosunkami gospodarczo-pienieżnymi w Polsce 1924-1939, Wyd. Wyższej Szkoły Ekonomicznej w Poznaniu, Poznań.

Taylor E., 1926, Druga inflacja polska. Prsycsyny - przebieg - środki zaradcze, Gebethner i Wolff, Poznań.

Taylor E., 1926a, Inflacja polska, Poznańskie Towarzystwo Przyjaciół Nauk, Poznań.

Taylor E., 1929, Polityka skarbowa i system podatkony Rzecsypospolitej Polskiej, WSH, Poznań.

Tomaszewski J., 1961, Stabilizacja waluty w Polsce 1924-1925, Książka i Wiedza, Warszawa.

Tymowski A., 1980, Polityka cen jako wyraz, preferencii spotecznych, Instytut Handlu Wewnętrznego i Usług, Warszawa.

www 1, https://stat.gov.pl [date of entry: 15.02.2018].

Zdziechowski J., 1925, Finanse Polski w latach 1924 i 1925, Biblioteka Polska, Warszawa 1925.

Zdziechowski J., 1937, Mit žtotej waluty, Instytut Wydawniczy Biblioteka Polska, Warszawa.

Zdziechowski J., 2005, Mit žłotej waluty, Dom Wydawniczy „Ostoja”, Warszawa

Zientara B., Mączak A., Ihnatowicz I., Landau Z., 1973, Drieje gospodarcze Polski do roku1939, Wiedza Powszechna, Warszawa.

Zweig F., 1923, Z łoty polski, Wyd. Towarzystwa Ekonomicznego, Kraków. 